\title{
Penerapan Pembelajaran Model Latihan Shadwo dalam Permainan Tenismeja di SMA Negeri 6 Kabupaten Tana Toraja
}

\author{
Nurlati Syamsuddin ${ }^{1}$, Nurul Musfira ${ }^{2}$, Nurussyariah Hammado ${ }^{3}$ \\ Universitas Negeri Makassar
}

\begin{abstract}
The application of the Shadwo training model socialization in the tennis game directly helped the tennis trainer to be able to utilize the available facilities to activate the athlete as a whole in the training practice process that was carried out at SMA Negeri 6 Tana Toraja. In addition, students indirectly realize that they will acquire skills that can support their ability to play tennis. Thus it can provide motivation to students to learn and practice so that they can play tennis well. The benefits of using the Shadwo training method in practicing jasmine can increase the quantity and quality of the ball that can be received in a short time. No time is wasted thinking when picking up the ball once it starts to rally and it is often easier for the coach to direct the ball to the right place, multiball is very useful for improving footwork, power, speed, reaction time, endurance and anticipation. And multiball is great for trying new things because it eliminates the fear of failure. This can help players trust and encourage development. Related to this, it can improve the ability of students so that students of SMA Negeri 6 Tana Toraja are able to play tennis. SMA Negeri 6 Tana Toraja Regency is a national level school, supported by very adequate facilities such as; fully equipped rooms and laboratories (chemical laboratories, physics laboratories, biology laboratories, computer laboratories, and language laboratories). In addition to this, the potential of human resources (teachers) is very supportive because they have participated in national-level training. On the other hand students at the school, support such as facilities and potential teachers are very well utilized. This is due to students going through the screening system as practiced by public schools in Tana Toraja Regency. Students who enter are students who are netted and have high intellectual and average family economic status. The school has an area of $11034 \mathrm{M}$ with a total of 28 teachers, 425 students. Sports facilities at the Tana Toraja State High School are basketball courts, takraw fields, badminton fields and tennis courts.The importance of sport is felt by humans in their daily activities. Many kinds of sports, one of which is table tennis. Table tennis is a sport that has many fans, not limited to the level of adolescence, but also children and parents, men and women are quite large in demand. This is because the game of table tennis is not too complicated to learn. Someone who wants to play table tennis well must learn basic techniques such as stroke or stroke. One type of punch that needs to be mastered is forehand and backhand.One way to realize the success of teaching and learning activities is the selection of appropriate and efficient learning methods and media, so students can receive and understand the subject matter. The position of the learning method in teaching and learning activities is very important.
\end{abstract}

Keywords : Training model, Shadwo

\section{PENDAHULUAN}

SMA Negeri 6 Kabupaten Tana Toraja merupakan salah satu sekolah yang bertaraf nasional, didukung oleh fasilitas yang sangat memadai seperti; ruangan dan laboratorium yang lengkap (laboratorium kimia, laboratorium fisika, laboratorium biologi, laboratorium komputer, dan laboratorium bahasa). Selain hal tersebut, potensi sumber daya manusia (guru) sangat menunjang sebab mereka telah mengikuti pelatihan-pelatihan yang bertaraf nasional. Disisi lain siswa yang ada di sekolah tersebut, dukungan seperti fasilitas dan potensi guru sangat dimanfaatkan sebaik-baiknya. Ini disebabkan siswa melalui sistem penjaringan sebagaimana yang dilakukan oleh sekolah-sekolah negeri yang ada di Kabupaten Tana Toraja. Siswa yang masuk adalah siswa yang terjaring dan memiliki intelektual yang tinggi serta status ekonomi keluarga rata-rata. Sekolah yang memiliki luas tana $11034 \mathrm{M}$ dengan jumlah tenaga guru 28 orang, siswa 425 . Fasilitas olahraga yang ada di sekolah SMA Negeri Tana Toraja yakni lapangan basket, lapangan takraw, lapangan bulu tangkis dan lapangan tenismeja. 
Pentingnya olahraga dirasakan oleh manusia dalam aktifitasnya sehari-hari. Olahraga banyak macamnya, salah satu diantaranya adalah tenis meja. Permainan tenis meja merupakan salah satu cabang olahraga yang banyak penggemarnya, tidak terbatas pada tingkat usia remaja, tetapi juga anak-anak dan orang tua, pria dan wanita cukup besar peminatnya. Hal ini disebabkan karena permainan tenis meja tidak terlalu rumit untuk dipelajari. Seseorang yang ingin bermain tenis meja dengan baik harus mempelajari teknik dasar seperti stroke atau pukulan. Salah satu jenis pukulan yang perlu dikuasai adalah pukulan forehand dan pukulan backhand.

Salah satu cara untuk mewujudkan keberhasilan kegiatan belajar mengajar adalah pemilihan metode pembelajaran dan media yang tepat dan efisien, sehingga siswa dapat menerima dan memahami materi pelajaran. Kedudukan metode pembelajaran dalam kegiatan belajar mengajar sangatlah penting.

Menurut Geoffry Wilson (1976) mengemukakan bahwa : "pengalaman belajar seseorang sebanyak $82 \%$ diperoleh melalui indra lihat, $18 \%$ melalui indra dengar. Dengan metode pembelajaran melalui media pembelajaran siswa akan tertarik dan tugas guru dalam menyampaikan materi akan lebih mudah dipahami dan tujuan pembelajaran dapat tercapai secara optimal karena persiapan materi yang telah direncanakan secara seksama dengan tetap mengacu pada kurikulum mata pelajaran.

Guru harus mengajarkan bagaimana siswa belajar dalam kegiatan pembelajaran. Sementara siswa belajar bagaimana seharusnya belajar melalui berbagai pengalaman belajar hingga terjadi perubahan dalam dirinya dari aspek kognitif, psikomotor dan afektif. Siswa akan belajar secara aktif jika rancangan pembelajaran yang disusun guru menuntut siswa melakukan kegiatan belajar. Rancangan pembelajaran yang mencerminkan kegiatan belajar secara aktif perlu didukung oleh kemampuan guru memfasilitasi kegiatan belajar selama proses pembelajaran berlangsung.

Dengan demikian ada korelasi signifikan antara kegiatan mengajar guru dan kegiatan belajar siswa. Mengaktifkan kegiatan belajar siswa berarti menuntut kreativitas dan kemampuan guru dalam merancang dan melakukan kegiatan pembelajaran.

Permainan tenis meja merupakan salah satu pokok bahasan yang diajarkan di sekolah termasuk di SMA Negeri 6 Kecamatan Rantetayo Kabupaten Tana Toraja ketinggalan dari sekolah lain. Seperti yang dikemukakan oleh Lusiana Patiku, S.Pd selaku guru olahraga di SMA Negeri 6 Kabupaten Tana Toraja dalam bermain tenis meja masih kurang, perlu pembinaan agar pengetahuan siswa tentang bermain terutama dalam melakukan tehnik dasar. Tehnik dasar dalam tenismeja sangatlah penting karena siswa mampu bermain diawali dengat tehnik dasar yang baik. Tehnik dasar tenis meja antara lain: Grip (Pegangan), Stance (Posisi), Stroke (Pukulan), Footwork (Olah langkah) oleh sebab itu pengenalan tentang tehnik dasar permainan tenis meja perlu ditingkatkan khususnya di kelas $\mathrm{X}$ yang tidak mampu memperlihatkan hasil belajar yang maksimal terutama dalam melakukan tehnik dasar, terkait dengan hal itu melalui latihan shadwo untuk belajar tehnik dasar akan mampu membantu mudah dan cepat meningkatkan kemampuan bermain tenismeja.

Dari uraian diatas adapun permasalahan yang timbul bahwa sejauh mana pengetahuan siswa kelas X tentang bagaimana melakukan tehnik dasar dengan baik. Dengan demikian saya selaku ketua merasa tertarik untuk mengadaka pengabdian kepada masyaraka tentang sosialisasi tentang penerapan pembelajaran model latihan shadwo dalam tenismeja pada siswa SMA Negeri 6 Kabupaten Tana Toraja.

Fenomena ini tidaklah menjadi sebuah hambatan sebagai salah satu sekolah negeri yang ada di Kabuapaten Tana Toraja, sebab segudang prestasi telah ditorehkan dan patut. Untuk permainan tenismeja di sekolah tersebut telah menjadi belum mampu menjadi icon dan ciri khas di dalamnya, sebab tidak memiliki pembinaan secara terprogram dan sistematis.

Berkaitan dengan proses pembelajaran pendidikan jasmani yang ada, masih jauh dari tujuan pembelajaran tersebut. Gaya mengajar yang dilakukan oleh guru 
dalam praktik pendidikan jasmani cenderung masih tradisional. Model metode-metode praktik dipusatkan pada guru (Teacher Centered) dimana para siswa melakukan latihan fisik berdasarkan perintah yang ditentukan oleh guru. Latihan-latihan tersebut hampir tidak pernah dilakukan oleh siswa sesuai dengan inisiatif sendiri (Student Centered). Guru pendidikan jasmani tradisional cenderung menekankan pada penguasaan keterampilan cabang olahraga. Pendekatan yang dilakukan seperti halnya pendekatan pelatihan olahraga. Dalam pendekatan ini, guru menentukan tugastugas ajarnya kepada siswa melalui kegiatan fisik tak ubahnya seperti melatih suatu cabang olahraga tenismeja pada teknik forehand. Kondisi seperti ini mengakibatkan tidak optimalnya fungsi pembelajaran pendidikan jasmani sebagai medium pendidikan dalam rangka pengembangan pribadi siswa seutuhnya.

Tehnik dasar dalam permainan tenismeja merupakan salah satu materi yang di ajarkan berdasarkan kurikulum penjas di SMA. Oleh karena itu, untuk menghilangkan sifat metode tradisional yang diajarkan selama ini dan memanfaatan fasilitas yang ada serta mencapai tujuan pendidikan jasmani, perlu adanya variasi strategi pembelajaran. Hal ini dilakukan untuk mengoptimalkan waktu, mengaktifkan siswa secara keseluruhan, memanfaatkan sarana yang terbatas, mengarahkan siswa untuk menguasai teknik yang didukung oleh kemampuan fisik, dan menunjang tingkat kebugaran siswa untuk dapat melanjutkan aktifitasnya serta mencapai tujuan pendidikan jasmani.

Untuk dapat menyelaraskan kemampuan tehnik dasar seperti pegangan, posisi, pukulan dan olah langkah dalam permainan tenismeja secara optimal, diperlukan inovasi dan kreatifitas guru untuk memilih alternatif strategi pembelajaran yang menekan pada aktivitas dan kebugaran siswa, sehingga proses belajar mengajar lebih optimal. Salah satu strategi pembelajaran yang dapat memperhatikan dan menekankan pada aktivitas secara keseluruhan dan mencapai kebugaran siswa adalah pembelajaran model latihan. Pembelajaran model latihan ini berupaya untuk memadukan materi teknik dan fisik dengan keadaan otentik yang ada di lingkungan serta mengoptimalkan penggunaan media pembelajaran untuk lebih mengkongritkan materi belajar seperti pukulan-pukulan dalam permainan tenismeja yang disampaikan. Proses pembelajaran model latihan ditekankan pada aktivitas siswa secara keseluruhan untuk aktif dan mendapatkan kebugaran serta pengetahuan yang diperoleh siswa menjadi utuh terpadu.

Proses pembelajaran model latihan membantu siswa dalam pengembangan pengalaman belajar, pengalaman belajar yang dimaksud adalah seperangkat kejadian yang berisikan aktivitas dan kondisi belajar untuk memberi strktur terhadap pengalaman siswa dan kejadian tersebut terkait untuk pencapaian tujuan. Misal dalam pembelajaran tenismeja, siswa diharapkan dapat melakukan tehnik dasar pegangan, posisi, pukulan dan olah langkah. Untuk itu seperangkat kejadian disusun dalam beberapa aktivitas belajar sebagai berikut:

1. Grip atau pegangan dengan shakend dengan posisi tangan seperti bersalaman jari telunjuk menghadap kebawah dengan ibu jari. Cara pegangan penholder dengan posisi tangan seperti memegang sendok atau penah.

2. Stance atau posisi : posisi badan agak condong kedepan lutut sedikit ditekuk kaki dibuka seebar bahu.

3. Stoke atau pukulan: setiap memukul bola jenis apapun pukulan selalu lengan posisi akhir membentuk sudut atau siku.

4. Footwork atau olah langkah: olah langkah untuk nomor tunggal misalnya 1 langkah, 2 langkah, 3 langkah. Untuk nomor ganda berbentuk huruf $\mathrm{N}$ terbalik, berbentuk huruf $\mathrm{T}$, berbentuk huruf $\mathrm{O}$ dan berbentuk huruf $\mathrm{V}$.

Pengalaman belajar ini harus direncanakan agar sesuai dengan konsep dasar pendidikan jasamani dan keterbatasan lapangan atau lingkungan belajar yang ada. Pada pembelajaran tenismeja salah satu model yang tepat untuk membantu cepat meningkatkan kemampuan siswa bermain tenismeja adalah latihan shadwo atau latihan bayangan. 


\section{METODE YANG DIGUNAKAN}

Tenismeja merupakan salah satu cabang olahraga yang mempergunakan bola kecil. Menurut sutarmin (2007:4) permainan tenismeja dikenal bangsa kira-kira pada tahun 1930. Pada waktu itu permainan tenismeja hanya dimainkan oleh keluarga dari belanda dan kelompok masyarakat tertentu saja, dan juga waktu itu olahraga tenismeja dimainkanuntuk mengisi waktu luang atau hanya rekreasi orang-orang belanda dibalaibalai pertemuan.

Permainan tenismeja merupakan permainan sangat unik dan bersipat kreatif, sehingga permainan tenismeja sangat digemari oleh sebagian besar lapisan masyarakat indonesia baik anak-anak, remaja, dan orang dewasa. Secara historis permainan tenismeja tidak diketahui secara pasti kapan pertama kali dimainkan dan siapa pertama kali memainkannya. Menurut sutarmin (2007), dari pengertian diatas dapat disimpulkan bahwa tenismeja adalah permainan yang menggunakan bola yang dipukul oleh seseorang pemain dengan menggunakan bolah kecil yang harus mampu melewati atau menyebrangi atas net dan mengembalikan bola kearah lawan setelah memantul di daerah permainan sendiri.

Sehubungan dengan hal itu, diperlukan keterampilan dasar yang baik dan benar selain didukung dengan faktor-faktor lainya. Menurut Bandi Utama (2004: 2) keterampilan permainan tenismeja antara lain: (a) pegangan (grip), (b) pukulan (stroke), sikap atau posisi bermain (stance), olah langka (footwork). Cara bermainnya adalah : bola di servis kearah lawan kemudian lawan membalas pukulan setelah bola memantul dari meja. Setiap dua kali servis terjadi pemindahan bola, angka kemenangan yang harus di capai adalah1 1 angka, jika terjadi 10-10 maka terjadi deuce. Tenismeja biasa dijadikan sebagai olahraga rekreasi dan bias juga berprestasi hal ini mempunyai arti bahwa jika sebagai olahraga rekreasi tenismeja hanya pengisi waktu senggang di kala berada di sekolah, waktu liburan, di kantor dan sebagainya. Sedangkan sebagai olahraga prestasi mempunyai arti bahwa kita harus berlatih belajar memahami dan mendalaminya dan menguasai berbagai pukulanpukulan dan macam-macam tipe permainan.

Menurut Simpson (1986:7) menyatakan bahwa : “ tenis meja bisa sebagai olahraga rekreasi dan bisa juga sebagai olahraga prestasi" hal ini mempunyai arti bahwa jika sebagai olahraga rekreasi, permainan tenis meja hanya sekedar pengisi waktu senggang dikala berada di sekolah, sedangkan sebagai olahraga prestasi mempunyai arti bahwa kita harus mempelajari dan memahami berbagai jenis pukulan dasar dan mengusai berbagai macam tipe permainan.

Dari langkah-langkah teknik dasar daslam permainan tenis meja maka pengenalan atau pendekatan pemahaman awal khususnya dalam pukulan backhand drive merupakan hal yang perlu diperhatikan seseorang yang baru bermain tenis meja. Dari uraian diatas yang perlu dipejari terlebih dahulu adalah teknik memegang bet. Seperti yang dijelaskan oleh Alex Mangundap (1992 : 10 ) bahwa teknik dasar ini ditempatkan pada urutan pertama mengingat bahwa kesan perhatian penonton terhadap seorang pemain tenis meja pertama adalah bagaimana cara memegang bet. Dari cara pegangannya sudah dapat dibayangkan tipe permainan dari pemain itu.

Permain antenis meja adalah salah satu jenis permainan yang menggunakan meja untuk memantulkan bola yang di pukul tersebut harus melewati net atau jaring yang di pasang pada bagian tengah meja".

1. Grip atau pegangan

Teknik memegang bet merupakan salah satu hal yang sangat penting untuk diperhatikan sebagai seorang pemain karena dengan cara memegang bet akan menentukan teknik permainan dan cara mengembangankan kualitas permainan. Pegangan dalam permainan tenis meja dapat dibedakan dalam dua bagian yaitu pegangan shakehand grip atau jabat tangan dan penhold grip.

2. Posisi badan atau stance

Stance atau posisi badan berarti posisi kaki atau badan dan tangan pada saat siap menunggu bola.

Dari penjelasan diatas, maka disarankan kepada pemain tenis meja untuk memperhatikan posisi yang 
baik agar keseimbangan badan tetap terjaga. Dimana dengan keseimbangan yang baik akan menghasilkan pukulan yang terarah.

\section{Footwork atau olah kaki}

Footwork adalah gerakan kaki dalam melakukan permainan tenis meja. Arah pergerakan footwork biasanya ke depan, belakang, kesamping kiri dan kanan. Penggunaan gerakan kaki disesuaikan dengan jarak yang harus diantisipasi antara bola yang datang dengan posisi pemain pada saat itu. Jika jarak sangat dekat tidak usah melangkah sedangkan jika jarak bola yang datang dengan posisi pemain pada saat itu agak jauh, maka bisa melangkah dua atau tiga langkah.

\section{Stroke atau pukulan}

Stroke adalah gerakan-gerakan pukulan yang dilakukan dalam permainan tenis meja. Stroke merupakan salah satu teknik dasar yang banyak digunakan dalam permainan tenis meja, karena itu teknik ini sangat perlu untuk dikuasai seorang pemain. Dalam permainan tenis meja kita mengenal banyak bentuk pukulan karena sikap dan gerak maka tercipta variasi-variasi pukulan seperti service, smash, topspin dan sebagainya. Tapi pada dasarnya seluruh rangkaian pukulan dalam permainan tenis meja bersumber dari jenis pukulan forehand dan backhand, namun yang menjadi fokus dalam penelitian ini adalah pukulan backhand drive.

Pukulan backhand drive merupakan pukulan dasar sehingga dijadikan sebagai bahan utama dalam permainan tenis meja bagi pemain tingkat pemula maupun bagi atlet yang sudah berada ditingkat lanjutan dimana teknik pukulan ini harus dilakukan dengan kualitas yang baik dengan memperhatikan sikap badan dan posisi kaki agar keseimbangan dalam memukul bola tetap terjaga dengan pukulan yang terarah.

a. Gerakan forehand adalah gerakan yang sangat terbatas, karena dibatasi oleh posisi tubuh khususnya gerakan mengayun tangan ke belakang. Oleh sebab itu otot-otot lengan tidak berkontraksi secara maksimal. Pada umumnya pusat gerak pada sendi siku (articulation cubiti) dan sendi pergelangan tangan articulation metacarpale).

b. Gerakan yang maksimal adalah atas bantuan gerakan pergelangan tangan. Oleh sebab itu luas gerak persendian tersebut sangat dibutuhkan.

5. Latihan bayangan atau latihan shadwo

Melakukan Shadow play dengan benar selalu akan memberikan keuntungan besar pada pemain tenis meja, baik yang sudah berpengalaman dan mahir maupun yang masih pemula. Berikut saran para ahli tentang latihan ini:

\section{Sisihkan waktu anda}

Sebagian besar orang melakukan "shadow play" (Latihan Bayangan) pada saat pemanasan saja. Kini saatnya anda melakukannya dengan serius di sesi tersendiri. Shadow play bisa menjadi latihan yang sangat bagus tidak hanya untuk mengeluarkan keringat saja. Dengan cara memperlambat gerakan dan memperhatikan secara serius pada bentuk gerakan pada saat stroke dalam latihan, anda akan mendapatkan peningkatan teknik dan mengadaptasikan otot anda dengan rasa gerakan yang benar."Ingat : 100 ayunan yang benar jauh lebih baik daripada 500 ayunan yang salah. Akhirnya anda akan meninggalkan gerakan yang salah"

\section{Lakukan di depan kaca}

Jika anda punya kaca yang bisa dipakai untuk melihat gerakan anda, lakukanlah latihan bayangan di depan kaca. Anda bisa mengabaikan semua pendapat tentang anda, kemampuan untuk melakukan pukulan anda sendiri dengan benar adalah tujuan utamanya.

3. Gunakan bet anda saat melakukan "Shadow Play"

Ini membantu otot anda untuk merasakan teknik dan feel yang benar, jika anda melakukannya tanpa bet hasilnya akan kurang maksimal."Beberapa pemain melakukannya dengan bet berat atau bet besi, namun untuk pemula lebih baik tidak melakukannya sampai tekniknya benar-benar sudah bagus. Bet berat rasanya berbeda dengan bet normal. Jika teknik anda sudah benar-benar solid maka bet berat bisa digunakan untuk mencapai pukulan yang lebih keras dan ayunan yang lebih cepat untuk putaran bola lebih cepat saat melakukan loop atau drive."

4. Posisi badan merendah 
Jangan lupa posisi badan anda harus merendah saat melakukan "Shadow Play". Merendah di sini adalah dengan menekuk lutut anda membentuk kuda-kuda yang solid untuk makin mendekatkan diri dengan pusat gravitasi. Jangan membungkukkan badan atas anda karena akan mengubah bentuk pukulan anda namum tekuklah lutut anda serendah mungkin untuk memudahkan anda bergerak ke mana saja dengan lebih cepat. Ingat, latihan ini bukan hanya untuk posisi bagian atas tubuh tapi juga latihan gerakan kaki, lekukan lutut dan putaran pinggang. Dan selalu bayangkan seolah-olah anda ingin atau sedang melakukan reli dengan lawan tangguh.

\section{Pandangan Fokus}

Pandangan anda harus tetap fokus saat melakukan latihan bayangan. Bayangkan bahwa anda melakukan pukulan bola saat dalam permainan sebenarnya. Ini akan membantu pikiran anda untuk ambil peran dalam proses ini. Dan terus tambah kecepatan untuk meningkatkan teknik anda.

6. Jika anda telah berkembang, cobalah teknik "Ghosting"

Teknik yang mengasumsi seolah-olah anda menghadapi pemain yang nyata. Teknik ini sering dilakukan oleh pemain squash Jonah Barrington di tahun 60-an dan 70-an. Jadi anda tidak harus mengulang-ulang gerakan yang sama setiap saat. Service, menerima bola, memukul bola dan sebagainya bisa anda variasikan tergantung dari image atau bayangan gerakan musuh yang anda ciptakan."Ingat: Ghosting adalah latihan yang berat maka lakukanlah perlahan-lahan dulu kemudian tambah kecepatan bila anda pikir sudah siap. Yang pasti "Ghosting" yang baik adalah gabungan dari "Shadow Play", fokus pandangan, dan latihan fisik. Itu semua akan membantu permainan tenis meja anda ke tingkatan yang lebih tinggi."

Tenis Meja adalah salah satu jenis cabang olahraga yang populer di Dunia.Di indonesia olahraga ini sudah tidak asing lagi. Olahraga ini dulunya sering disebut Ping-pong. Permainan ini belum dapat diketahui secara pasti dari mana asalnya,siapa penemunya dan kapan ditemukan. Permainan ini mulai dikenal mulai kenal oleh masyarakat sekitar tahun 1890.kemudian mengalami pasang surut. Baru pada tahun 1920-an, permainan tennis meja mulai berkembang lagi dengan munculnya klub-klub tennis meja di seluruh dunia, terutama di Eropa.Di Indonesia Olahraga ini sudah cukup populer dikalangan masyarakat.Berbagai event sudah banyak digelar baik dilevel perkampungan,regional maupun nasional.Di level nasional olahraga ini selalu dipertandingkan dalam kejuaran multievent sperti PON dan di level provinsi juga dipertandingkan pada PORPROV. Tetapi banyak dikalangan masyarakat banyak yang asal-asalan dalam bermain tenis meja tanpa mengetahui teknik dasar yang benar.

Dalam bermain tenis meja setiap pemain harus menguasai berbagai jenis pukulan yang ada. Terdapat banyak jenis pukulan dalam permainan ini seperti pukulan Drive,Chop, dan masih banyak lagi. Dalam bermain tenis meja hendaknya mngetahui berbagai pukulan tersebut.Selain berbagai jenis pukulan juga ada teknik block,juga ada teknik servis. Agar permainan baik dan tidak asal-asalan harus menguasai teknik dasar secara keseluruhan.Mulai bagaimana teknik servis, teknik blocking,sampai berbagai jenis pukulan. Semua itu harus dikuasai karena itu adalah suatu kesatuan yang utuh dalam bermaian tenis meja.

Setelah mengetahui teknik dasar yang benar diharapkan pemain dapat bermain dengan baik dan dapat meminimalisir kesalahan-kesalahan yang terjadi dalam bermain tenis meja.Diharapkan dapat meningkatkan dan mengembangkan teknik dan pola yang sudah ada dengan latihan yang rutin dan berulang-ulang dapat meningkatkan teknik sehingga lebih sempurna dalam bermain tenis meja.

Tenis Meja adalah salah satu jenis cabang olahraga yang populer di Dunia. Permainan ini belum dapat diketahui secara pasti dari mana asalnya,siapa penemunya dan kapan ditemukan. Permainan ini mulai dikenal mulai kenal oleh masyarakat sekitar tahun 1890. Supaya dapat bermain dengan baik diharapkan pemain harus mengerti dan mengetahui teknik dasar bermain tenis meja tersebut. Ada banyak teknik yang harus dikuasai oleh pemain misalnya pukulan, servis dan sebagainya. Dalam bermain tenis meja hendaknya 
mengetahui berbagai pukulan. banyak jenis pukulan dalam permainan ini seperti pukulan Drive,Chop, dan masih banyak lagi.

a. Pembelajaran model latihan

Gagne (dalam Anon,

2003)

mengungkapkan bahwa: "Pembelajaran adalah usaha yang bertujuan untuk menolong siswa. Pembelajaran merupakan seperangkat peristiwa yang mempengaruhi siswa sebagai cara yang memungkinkan proses belajar dapat terjadi". Hal ini berarti bahwa pembelajaran sebagai penyediaan kondisi untuk proses belajar. Pembelajaran merupakan usaha manusia yang dilakukan dengan tujuan untuk membantu memfasilitasi belajar orang lain (Setyosari, 2001). Secara khusus pembelajaran merupakan upaya yang dilakukan oleh pembelajar, instruktur, pembelajaran dengan tujuan untuk membawa siswa agar ia belajar dengan mudah Pembelajaran juga dimaksudkan sebagai suatu proses yang diarahkan untuk mencapai suatu tujuan yang direncanakan lebih dulu. Disamping itu Setyosari (2001) mengatakan bahwa:

Pembelajaran adalah penyajian informasi dan aktifitas-aktifitas yang dirancang untuk membantu memudahkan siswa dalam rangka mencapai tujuan khusus belajar yang diharapkan, dengan kata lain, pembelajaran adalah wujud tindakan dari aktifitas-aktifitas yang difokuskan pada siswa yang mempelajari hal-hal khusus.

Menurut Degeng (1997) bahwa: "Metode pembelajaran adalah cara-cara yang berbeda untuk mencapai hasil pembelajaran yang berbeda di bawah kondisi yang berbeda". Dengan kata lain cara-cara yang dipakai untuk menyampaikan pelajaran kepada siswa, dan sekaligus untuk menerima serta merespon masukan-masukan dari siswa. Metode dan strategi sering digunakan secara bergantian untuk menjelaskan makna yang sama. Metode pembelajaran diacukan sebagai cara-cara yang dapat digunakan dalam kondisi tertentu untuk mencapai hasil pembelajaran yang diinginkan. Sedangkan, strategi pembelajaran diacukan sebagai penataan cara-cara, sehingga terwujud urutan langkah-prosedur yang dapat digunakan untuk mencapai hasil yang diinginkan. Metode pembelajaran merupakan salah satu faktor yang menentukan keberhasilan suatu program. Metode pembelajaran merupakan komponen penentu utama kualitas pembelajaran, demikian pentingnya metode pembelajaran, sehingga harus dipilih dengan sebaikbaiknya (Dahar, 1991). Pemilihan metode pembelajaran harus didasarkan pada analisis kondisi dan hasil pembelajaran (Degeng dan Miarso, 1993). Hal ini karena kondisi dan hasil pembelajaran tidak dapat dimanipulasi oleh pembelajar pada umumnya, hanya terbatas pada metode pembelajaran.

Pendekatan model latihan adalah suatu proses penyampaian pengajaran dalam bentuk-bentuk latihan yang mengacu pada bermain tanpa mengabaikan materi inti. Latihan yang dimaksukan disini adalah kegiatan atau aktifitas yang materinya disesuaikan dengan standar kompetensi dalam kurikulum. Pendekatan model latihan diarahkan untuk membantu siswa agar lebih cepat terampil dalam sebuah materi pelajaran. Jadi dengan demikian permainan dikonsentrasikan pada pendekatan memahami masalah yang didasarkan atas domain kognitif, dirancang oleh guru untuk mengarahkan siswa memahami kegiatan dan tujuan keterampilan dalam kegiatan tersebut. Pendekatan ini memungkinkan guru untuk membantu kelompok kecil atau individu yang tekniknya masih kurang. Pembelajaran model latihan ini merupakan panduan dalam melakukan praktik untuk memperoleh teknik dan fisik siswa, di mana dalam praktik pembelajaran model latihan, guru diharapkan dapat menerapkan prinsip-prinsip pembelajaran dalam kegiatan belajar mengajar dan memanfaat sarana prasarana pembelajaran yang ada dengan tujuan pembentukan kemampuan, serta menerapkan keterampilan dasar mengajar secara utuh dan terintegrasi. Pembelajaran model latihan diharapkan untuk mencapai tujuan pelajaran yang mempunyai dampak dalam proses belajar mengajar, Bafirman (1996) mengungkapkan sebagai berikut:

1. Menempatkan permainan kecil menjadi fokus dari mata pelajaran pendidikan jasmani yang dapat meningkatkan kegembiraan dan kepuasan pada diri siswa dalam melakukan gerakan-gerakan untuk 
bermain, dalam rangka mencapai unsur kesegaran jasmani.

2. Memungkinkan siswa yang kurang terampil berolahraga dan kurang menyenangi olahraga akan menyenangi kegiatan jasmani atau olahraga seperti kawan-kawan lain yang secara jasmaniah berbakat dalam olahraga.

3. Mendorong siswa untuk belajar mengambil keputusan mereka sendiri dalam waktu yang sangat singkat.

4. Keterampilan olahraga tidak mutlak harus dimiliki oleh siswa laki-laki saja tetapi siswa perempuan harus mampu untuk melakukannya.

Jadi dengan demikian dari pendapat pakar di atas maka dapat kita hubungkan dengan kenyataan yang ada, maka gerakan model latihan pada siswa akan membantu dirinya sendiri untuk lebih cepat terampil menguasai gerakan-gerakan yang diajarkan. Dengan adanya unsur model pembelajaran bermain yang dimunculkan dalam setiap pertemuan dengan siswa dalam proses belajar mengajar baik itu untuk pemanasan maupun pelajaran inti atau kegiatan akhir, maka kita sebagai seorang guru pendidikan jasmani dapat membantu siswa untuk mencapai salah satu unsur tujuan pendidikan jasmani yaitu kebugaran. Pembelajaran model latihan dapat digunakan untuk mengajar atletik, senam dan permainan olahraga lainnya yang ada hubunganya dengan pendidikan jasmani di dalam kurikulum yang dirancang melalui rencana pengajaran.

\section{HASIL DAN PEMBAHASAN}

Pada saat acara pembukaan instruktur atau pemateri menjelaskan Teknik Dasar Olahraga Tenismeja yaitu; meningkatkan kemampuan pukulan forehand dan backhand melalui metode latihan shadwo. Selanjutnya Pemateri melakukan diskusi dan tanya jawab dengan peserta untuk mengetahui sejauhmana mereka dapat memahami materi yang telah disampaikan. Setelah peserta dianggap memahami secara keseluruhan, maka pertemuan hari berikutnya dilakukan praktek di lapangan dengan bermain tenismeja. para peserta telah mempraktekkan materi yang telah diterima misalnya dengan menggunakan kostum yang islami, para peserta dapat bekerjasama dengan tim dan bermain secara sportif. Pada saat evaluasi semua peserta menguasai secara keseluruhan baik teori maupun praktek.

Pelaksanaan program kemitraan masyarakat ini berlangsung selama 2 (dua) hari dengan melibatkan siswa-siswi dan guru olahraga SMA Negeri 6 Tana Toraja, para peserta menunjukkan keseriusan dan antusias menyimak dan mendengarkan penjelasan pemateri tentang Teknik Dasar Permaninan tenismeja sebagai bahan teori dan peningkatan kemampuan pukulan forehand dan pukulan backhand melalui latihan shadwo atau latihan bayangan.

Hasil dari kegiatan program kemitraan masyarakat ini yang dilaksanakan di sekolah SMA Negeri 6 Tana Toraja menunjukkan hasil yang sangat positif, hal ini dapat dibuktikan bahwa berdasarkan hasil evaluasi yang dilakukan maka seluruh perserta program kemitraan masyarakat dinyatakan memahami dengan baik materi yang telah disampaikan.

Namun dari hasil yang telah dicapai selama pelaksaan program kemitraan masyarakat ini, juga tidak terlepas dari beberapa kendala yang dialami dalam pelaksanaannya, daiantaranya adalah keterbatasan waktu yang tersedia. Meskipun demikian kegiatan program kemitraan masyarakat ini tetap berjalan sesuai jadwal yang telah ditentukan.

Adapun hasil yang dicapai dalam kegiatan program kemitraan masyarakat tersebut adalah sebagai berikut: Rata-rata semua peserta yang mengikuti kegiatan ini mampu memahami dan mengerti tentang pentingnya latihan shadwo dalam meningkatkan kemampuan pukulan forehand dan pukulan backhan

Hasil dari kegiatan program kemitraan masyarakat ini merupakan bekal yang sangat berharga bagi peserta apalagi sebagai mahasiswa calon guru ataupun sebagai calon pelatih dalam mempersiapkan dirinya untuk mengajarkan penjas dengan mengintegrasikan nilainilai agama dalam proses pembelajaran atau sebagai pelatih dapat ditularkan ilmunya kepada para atlit binaannya. 


\section{KESIMPULAN}

Dalam pelaksanaan kegiatan pelatihan penerapan ini terdapat keseimpulan sebagai berikut:

1. Dengan penuh harapan dukungan dari Ibu Dekan Fakultas Ilmu Keolahragaan Universitas negeri Makassar dan ketua Lembaga Pengabdian Kepada Masyarakat Universitas Negeri Makassar maupun yang terkait dalam penerapan sosialisasi pembelajaran model latihan shadwo dalam permainan tenismeja di SMA Negeri 6 Kabupaten Tana Toraja baik moril maupun materil. Tanpa ada dukungan dari ibu dan bapak kegitan ini tidak bisa terlaksana.

2. Penerapan sosialisasi model latihan teknik forehand dalam permainan tenismeja, secara langsung membantu guru pendidikan jasmani untuk dapat memanfaatkan sarana yang ada, guna mengaktifkan siswa secara keseluruhan dalam proses pembelajaran yang dilaksanakan di sekolah tersebut. Disamping itu, siswa secara tidak langsung menyadari akan memperoleh kebugaran yang dapat menunjang aktifitas selanjutnya. Dengan demikian dapat memberikan motivasi kepada siswa untuk menjadi pemain tenismeja.

\section{DAFTAR PUSTAKA}

Dini Rosdiani. 20013.Perencanaan Pembelajaran dalm Pendidikan Jasmani dan kesehatan. Bandung: ALFABETA.
Anon. 2003. Pedoman Pembelajaran Tuntas. Jakarta: Ditjen Dikdasmen Depdiknas.

Bafirman . 1996 . Pembinaan Kesegaran Jasmani. Padang: FPOK IKIP Padang.

Dahar R.W. 1991. Teori-teori Belajar. Jakarta: Departemen Pendidikan dan Kebudayaan P2LPTK.

Degeng, I.N.S. dan Miarso, Y. 1993. Desain Pembelajaran: Teori dan Terapan. Malang: FPS IKIP Malang.

Degeng I.N.S. 1997. Strategi Pembelajaran: Mengorganisasi Isi dengan model Elaborasi. Malang: IKIP Malang dan IPTPI.

Sanusi, arsyad. 1980. Tenis meja untuk seтиа uтиr. Ujung pandang. KONI SUL-SEL.

Simpson, Peter, 1986. Tekhnik bermain pimpong. Pionir jaya, bandung.

Soetomo. 1981. Tenis meja, suatu penguraian dalam buku olahraga untuk perguruan tinggi, jakarta : PT. Sastra Budaya.

Achmad damiri dan nurlan kusmedi (1992 : 30) : Table tenis FIK mengundap dan jance tulalessy (1992:10) : “ dasar-dasar tenis meja dan tehnik tenis meja fik unm “

Achmad, damiri, kusmedi, nurlan. 1992. Tenis meja. Bandung : Depdikbut Dirjen dikti, proyek pembinaan pendidikan.

Setyosari. P. 2001. Rancangan Pembelajaran Teori dan Praktis. Malang: Elang Mas.

Supandi. 1992. Strategi Belajar Mengajar Pendidikan Jasmani dan Kesehatan. Jakarta: Depdikbud Ditjen Dikti PPTK. 